\title{
Acute and Subacute Effect of LH-RH upon LH- and FSH-Gonadotrophs in Castrated Female Rats with Short-Term Estrogen-Progesterone Pretreatment*
}

\author{
Tsuyoshi SOJI, ${ }^{* *}$ KazUyoshi TAYA, ${ }^{* * *}$ MaSAo IGARASHI ${ }^{* * *}$ \\ AND FUJIO YOSHIMURA** \\ ** Department of Anatomy, Jikei University School of Medicine, \\ Minatoku, Tokyo 105 and ***Department of Obstetrics and Gynecology, \\ School of Medicine Gunma University, Maebashi 371
}

\section{Synopsis}

Acute effect of synthetic LH-RH upon LH- and FSH-gonadotrophs in prepuberally ovariectomized female rats 3 days after a short-term estrogen-progesterone treatment was investigated electron microscopically along with the radioimmunoassay of LH and FSH. Thirty days after ovariectomy, so-called central LH-gonadotrophs dispersed, but the castration cells which might originate from FSH-gonadotrophs accumulated in the central area of the gland; most of peripheral LH-gonadotrophs became slightly affected, although there was a possibility that some of them took an appearance of castration cells. Secretory granules were considerably driven out of castration cells filled with dilated cisternae. Following the estrogen-progesterone pretreatment, some peripheral castration cells quickly dispersed and normal ovoid LH-gonadotrophs filled with secretory granules appeared again. Central castration cells were not, however, recovered from their cell hypertrophy, but from the reduction in size of cisternae. Steroid pretreatment thus could enough prevent the release of granules from the castration cells. Those rats were i.v. injected with $\mathrm{LH}-\mathrm{RH} 100 \mathrm{ng} / \mathrm{ml} / \mathrm{rat} 33$ days after the castration. Serum LH was highest after 5 and $10 \mathrm{~min}$, but mean pituitary LH content was unchanged through the testing periods except for diminution at 5 and $180 \mathrm{~min}$. Serum FSH concentration rose slightly, but mean pituitary FSH content showed no change except for diminution at 5 and $180 \mathrm{~min}$. Morphologically, LH-RH temporally and slightly deprived peripheral LH-cells of the secretory granules within 5 min and made central LHcells visible again within 5 and $10 \mathrm{~min}$ through their granulation. On the other hand, LH-RH exerted the primary effect upon FSH-castration cells to drive out transiently but efficaciously the secretory granules within 5,10 min or later, along with the more profound contraction of cisternae. The interval of 5 min may be assumed as the "discharging phase" of LH-gonadotrophs, and the interval between 5 and 10 min as "primary short-term discharging phase" of FSH-gonadotrophs. Subsequently, both kinds of gonadotrophs began to reproduce their secretory granules. The interval between 10 and 30 min may be called "synthesizing phase" of FSH-gonadotrophs; the interval up to 60 min may represent the "storage phase" taking the form of FSH-castration cells. LH-RH exerted the secondary, mild but prolonged effect of granular discharge upon FSH-castration cells within 180 min causing a transformation into the typical castration cell with numerous open cisternae. Signet-ring cells were, however, scarcelly changed in response to this dose of releasing hormone. It was concluded that $\mathrm{LH}-\mathrm{RH}$ would act not only slightly upon LH-gonadotrophs but also biphasically upon FSH-gonadotrophs to discharge the secretory granules which may be associated with LH secretion both in acute and subacute periods. Evidences for the intrinsic capacity of so-called FSH-gonadotrophs to secrete $\mathrm{LH}$ in contradiction to their name are now available. It is therefore quite hard to identify certainly LH-gonadotroph with FSH-gonadotroph on the basis of their morphological criteria.

\footnotetext{
Received for publication July 31, 1974.

- Financially supported, in part, by a grant of Scientific Reserach from the Educational Ministry of Japan (No. 748049).
}

Reprints: To F. Yoshimura, Department of Anatomy, Jikei University School of Medicine, Minatoku, Tokyo 105 
Mendoza et al. (1973) examined the acute effect of LH-RH upon the LH-gonadotrophs immunocytochemically and electron microscopically in intact and castrated rats after the injection of LH-RH: A major change in the LH-gonadotrophs pointed out by these authors was the release of secretory granules by extrusion system accompanied by neither hypertirophy nor hypergranulation. Chronic effect of LH-RH upon the LH- and FSHgonadotrophs was, on the other hand, examined by Debeljuk et al. (1973) and Arimura et al. (1973) in hypophysectomized pituitarygrafted rats: Long-term treatment with $\mathrm{LH}$ $\mathrm{RH}$ prevented both kinds of gonadotrophs, especially FSH-cells, from their atrophy or retrogession in the pituitary grafts, inducing remarkable cell hypertrophy and enlargement of Golgi area associated with the initiation of active granulation in the FSH-gonadotrophs, as well as a stimulation on the ovarian follicles.

The fundamental basis for identification of LH-cells made by Schally and his co-workers (Mendoza et al., 1973; Debeljuk et al., 1973) seems succed to the view of Kurosumi (1968) and Rennels and his associates (Shiino et al., 1972). Despite many immunohistochemical and electron microscopic investigations on the LH-secreting cells (Barnett et al., 1956; Herlant and Ectors, 1969; Bain and Ezrin, 1070; Nakane, 1070; Dubois, 1971; Mirecka and Pearse, 1971; Baker et al., 1972; Phifer et al., 1973), there is still a confusion as to the identification of LH- and FSH-gonadotrophs between immunohistochemical and electron microscopic findings. Yoshimura et al. (1974) compared the light and electron microscopic findings of the same peripheral LH-cell on the adjacent two slices to dissolve this confusion: They assumed them to belong to the cells in the prestage of functional cycle of FSH-cells. In other words, LH- and FSH-cells are not the independent cell types of respective gonadotrophin secretion, but represent two different phases of secretory cycle conducted in a basophil.
Using the female rats castrated and pretreated with steroids, what a kind of gonadotroph is deprived of the stored secretory granules in response to $\mathrm{LH}-\mathrm{RH}$ was investigated. In this study, some correlation between the quantitative changes of granules in castration cells developing from FSH-gonadotrophs and the pituitary and serum LH and FSH content was suggested to facilitate the identification of real LH-secreting cell.

\section{Materials and Methods}

Wistar-Imamichi female rats were ovariectomized on the 30th day of birth, followed by subcutaneous injection of estrogen (estradiol benzoate $100 \mu \mathrm{g} / \mathrm{rat}$ ) and progesterone $(5 \mathrm{mg} / \mathrm{rat})$ in combination 30 days later. These animals were used for this experiment after an interval of 3 days, being dividing into six groups, of 4-5 rats each, i.e., control group with physiological saline $(1 \mathrm{~m} / / \mathrm{rat})$ and groups sacrificed 5, 10, 30, 60 and $180 \mathrm{~min}$ respectively after the injections of LH-RH. Synthetic LH-RH, $100 \mathrm{ng} / \mathrm{ml} / \mathrm{rat}$ (Dai-ichi Seiyaku Co., Ltd.) was injected into the jugular vein. The control animals were sacrificed $10 \mathrm{~min}$ after the injection of saline.

Blood samples were obtained from the jugular vein under ether anesthesia, allowed to clot at room temperature, and then cenrifuged. Serum was stored at $-20^{\circ} \mathrm{C}$ until the assay. Anterior pituitary glands were removed immediately after sacrifice, and weighed. One half of the gland was used for electron microscopic examination, and the other half was homogenized in saline. The extracts were stored at $-20^{\circ} \mathrm{C}$ until the assay.

The sera and pituitary extracts from 4 or 5 rats were pooled in each same group. FSH and $\mathrm{LH}$ concentrations in the sera and pituitary extracts were determined, using the NIAMD rat FSH-RP-1 and LH-RP-1 radioimmunoassay method according to the method of Daane and Parlow (1971) slightly modified by Wakabayashi et al. (1972).

For the electron microscopy, pituitary tissues were fixed in $2 \%$ osmic acid in a pH 7.4 veronal acetate buffer solution for $2 \mathrm{hr}$. Following fixation the tissues were dehydrated in an increasing percentage of cold ethanol, treated with propylenoxyde for $10 \mathrm{~min}$, infiltrated and embedded with Luft's epoxy resin 812 . Thin sections were made with Porter-Blum ultratome, and stained with a saturated uranyl acetate solution and then with the lead solution of Reynalds (1963). The sections were examined under a JEM 7 and $100 \mathrm{~B}$ type electron microscope. 


\section{Results}

1. Serum and pituitary LH and FSH concentrations after an intravenous injection of LH- $R H$

Sequential changes in serum $\mathrm{LH}$ and FSH levels after an intraveous injection of LH-RH are summarized in Figure 1: Control castrated rats after short-term estrogen-progesterone treatment showed serum FSH of $2.8 \pm 0.2$ $\mu \mathrm{g} / \mathrm{m} l$ and serum LH of $205.3 \pm 40.0 \mathrm{ng} / \mathrm{ml}$. Serum LH level rose immediately after the injection, followed by a decrease to almost the normal level after 60 and $180 \mathrm{~min}$. Serum FSH level, however, tended to rise slightly, reaching the highest level $(3.5 \pm 0.4 \mathrm{~g} / \mathrm{m} l)$ after $60 \mathrm{~min}$, followed by a gradual drop for the next $180 \mathrm{~min}$.

Changes in pituitary LH and FSH contents are summarized in Figure 2. Mean pituitary LH and FSH contents showed no elevation from the control values of $2387.13 \pm 319.93$ $\mu \mathrm{g} /$ pit and $218.08 \pm 42.83 \mu \mathrm{g} /$ pit respectively up to $60 \mathrm{~min}$ after injection. After $180 \mathrm{~min}$, pituitary $\mathrm{LH}$ and FSH contents, however, droped together to the lowest level (1061.73 \pm $276.63 \mu \mathrm{g} /$ pit and $113.59 \pm 25.20 \mu \mathrm{g} /$ pit respectively) below the control.

\section{Morphological changes in gonadotrophs in} the castrated control rats with or without the steroids pretreatment

Thirty days after castration, peripheral "LH-gonadotrophs" did not give rise to the definite affection as the chronic effect. Their main changes following castration without the steroid pretreatment were gradual reduction in number of secretory granules and onset of occurrence of round cisternae (Fig. 3). A possibility that peripheral LH-gonadotrophs turn into vesiculated castration cells is neither denied nor confirmed by the present observation, although FSH-gonadotrophs are susceptible to transform into castration cells in the central area of the gland (Fig. 4). The castration cells originating from the FSH-

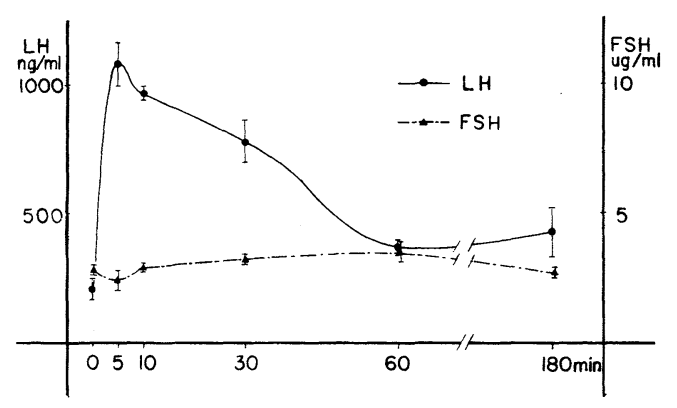

Fig. 1. Serum LH and FSH concentrations after an i.v. injection of LH-RH in castrated female rats following short-term steroids pretreatment, expressed in terms of NIAMD-RAT-LH-RP-I, NIAMDRAT-FSH-RP-I and $\mathrm{mIU} / \mathrm{m} l$. Five rats were used in each group. A vertical bar represents the mean \pm S.E.

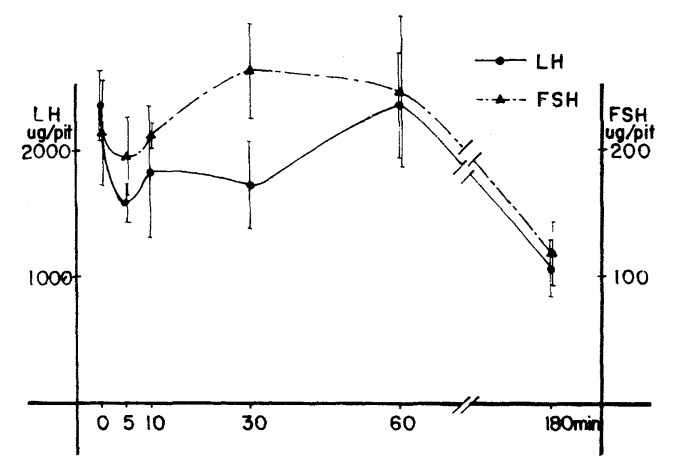

Fig. 2. Pituitary LH and FSH concentrations after an i.v. injection of $\mathrm{LH}-\mathrm{RH}$ in castrated female rats following short-term steroids pretreatment, expressed in terms of NIAMD-RAT-LH-RP-I, NIAMD-RAT-FSH-RP-I and $\mathrm{mIU} / \mathrm{m} l$. Five rat anterior pituitaries (a half) were pooled in the same group. A vertical bar represents the mean \pm S.E.

gonadotrophs are characterized by dense distribution of dilated, irregularly shaped ER, dimensional expansion of ring-like arrangement of Golgi vacuoles or lamelles and relatively small number of storage granules. Central LH-gonadotrophs were no longer detected following castration without steroid pretreatment because of showing rapid serious modification of their fine structure.

Following a single steroid injection after castration, response of peripheral LH-gonado- 

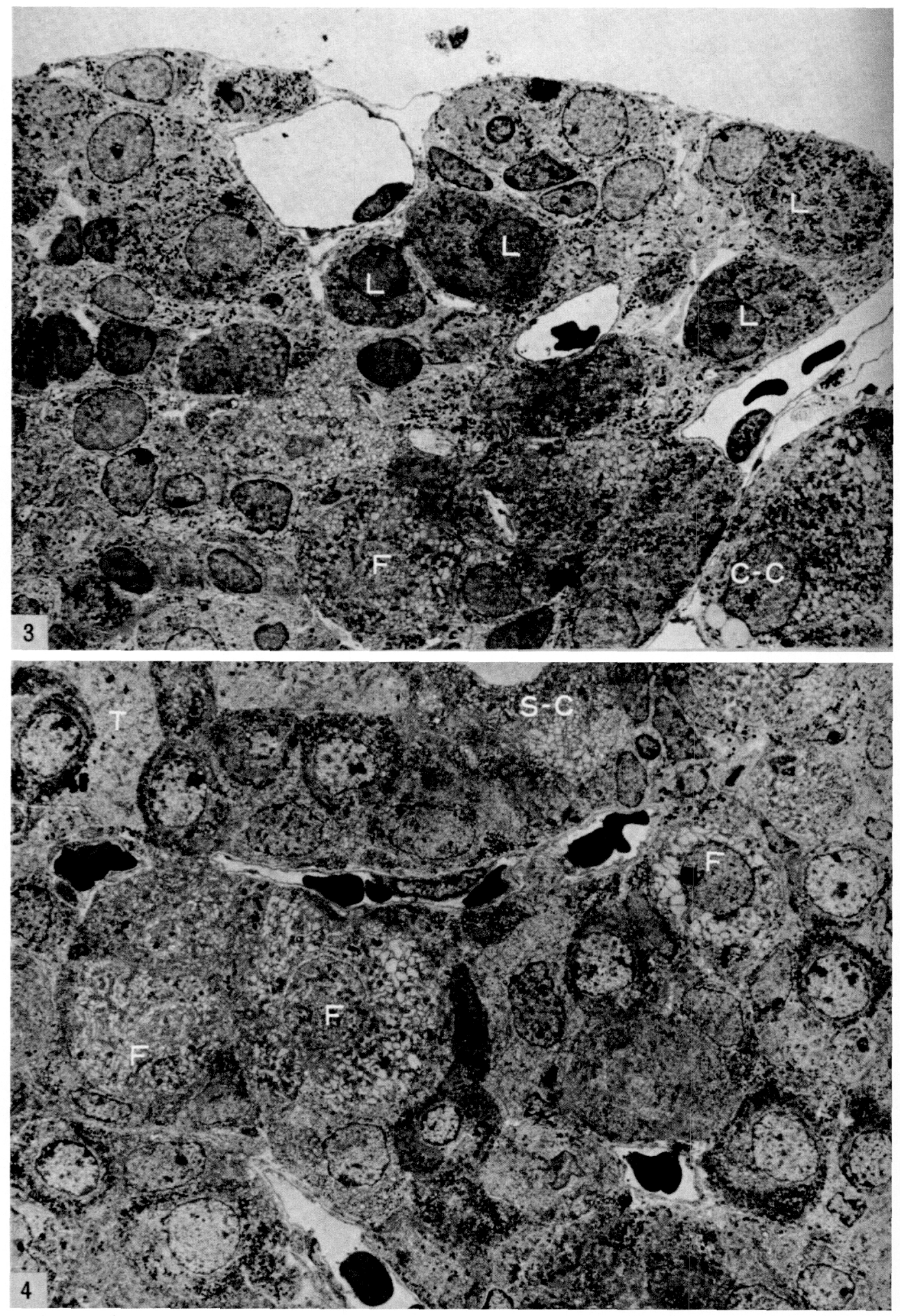
trophs to castration is arrested as shown in Figure 5. Dense secretory granules synonymous with storage carriers of hormones are accumulated in peripheral LH-gonadotrophs (L), and numerous large round cisternae, specific to castration cells, are shrunk only 3 days after injection. This storage granular type of perpheral LH-gonadotrophs represents the normal picture. On the other hand, in the majority of castration cells developing from FSH-gonadotrophs at the central area of the gland, the size of vacuoles and cisternae becomes considerably reduced and their cytoplasmic ground matrix contains numerous dense granules (Fig. 6). Consequently, inhibited granular release and promoted hypergranulation seem to take place simultaneously. However, some signet-ring cells remained unchanged without any sign of recovery by this pretreatment.

3. Changes on LH- and FSH-cells, 5 min after an intraveuous injection of $\mathrm{LH}-\mathrm{RH}$

Through the comparison of Figure 7 with Figure 5 was found a tendency of decrease in number of secretory granules of about 200 to $250 \mathrm{~m} \mu$ in diameter in the LH-gonadotrophs after LH-RH injection. Notwithstanding the variation in number of the granules among LH-cells, moderate reduction in number could be perceptible under high magnification in Figure 8. No direct discharge of secretory granules by extrusion system was detected throughout this acute experiment. In fully developed castration cells (C-C, in Figs. 7 and 8) no serious affection was found as to ER and secretory granules. Within $5 \mathrm{~min}$, various stages of transitional cells ranging from usual FSH-cells to castration cells were found in the central area of the gland (Fig. 9). Most of them belonged to the enlarged FSH-gonado- trophs or immature castration cells with closed cisternae, among which fully developed castration cells filled with the dilated, irregularly shaped ER were occasionally interspersed (C-C in Fig. 9). Quantitative decrease of secretory granules in response to acute LH$\mathrm{RH}$ administration was less pronounced in immature castration cells (Figs. 9, 10, 11). The activity of this releasing hormone was thus morphologically proved to moderately drive out the secretory granules from the enlarged FSH-gonadotrophs. Although numerous enlarged FSH-gonadotrophs in the control rats contain the atrophic cisternae (Fig. 6), LH-RH failed to facilitate the recovery from the shrinkage of cisterae. In a certain ovoid FSHcells deprived of granules, ER were so extensively shrunk that these cells resembled, in fine structural property and cell shape, socalled LH-cells (Fig. 11). In contrast to the absence of central LH-cells in the controls, an injection of LH-RH caused their rapid reappearance.

\section{Changes on LH- and FSH-cells, $10 \mathrm{~min}$ after $\mathrm{LH}$-RH injection}

Within 10 min, many peripheral LH-cells began to regranulate after the primary discharging phase, followed by storage of a large number of secretory granules. Despite temporary and slight discharge of secretory granules from the peripheral LH-cells only in $5 \mathrm{~min}$, their granules already reappeared within $10 \mathrm{~min}$ (Fig. 12). There was, on the other hand, definite difference in the degree of granulation among FSH-gonadotrophs. Some cells were devoid of the granules, some others have abundant storage. Under the low magnification of electron micrographs, the storage granules showed the lowest concentration in the central area of the gland after $10 \mathrm{~min}$ (Fig.

$\leftarrow$ Fig. 3. Superficial region of the anterior pituitary from a female rat ovariectomized on the 30 th day, 30 days after the operation $\times 2,000$. L, LH-gonadotroph; F, FSH-gonadotroph; C-C, castration cell.

Fig. 4. Central area of the gland from the same rat, $\times 3,000$. S-C, signet-ring cell; T, thyrotroph; F, FSH-gonadotroph. 

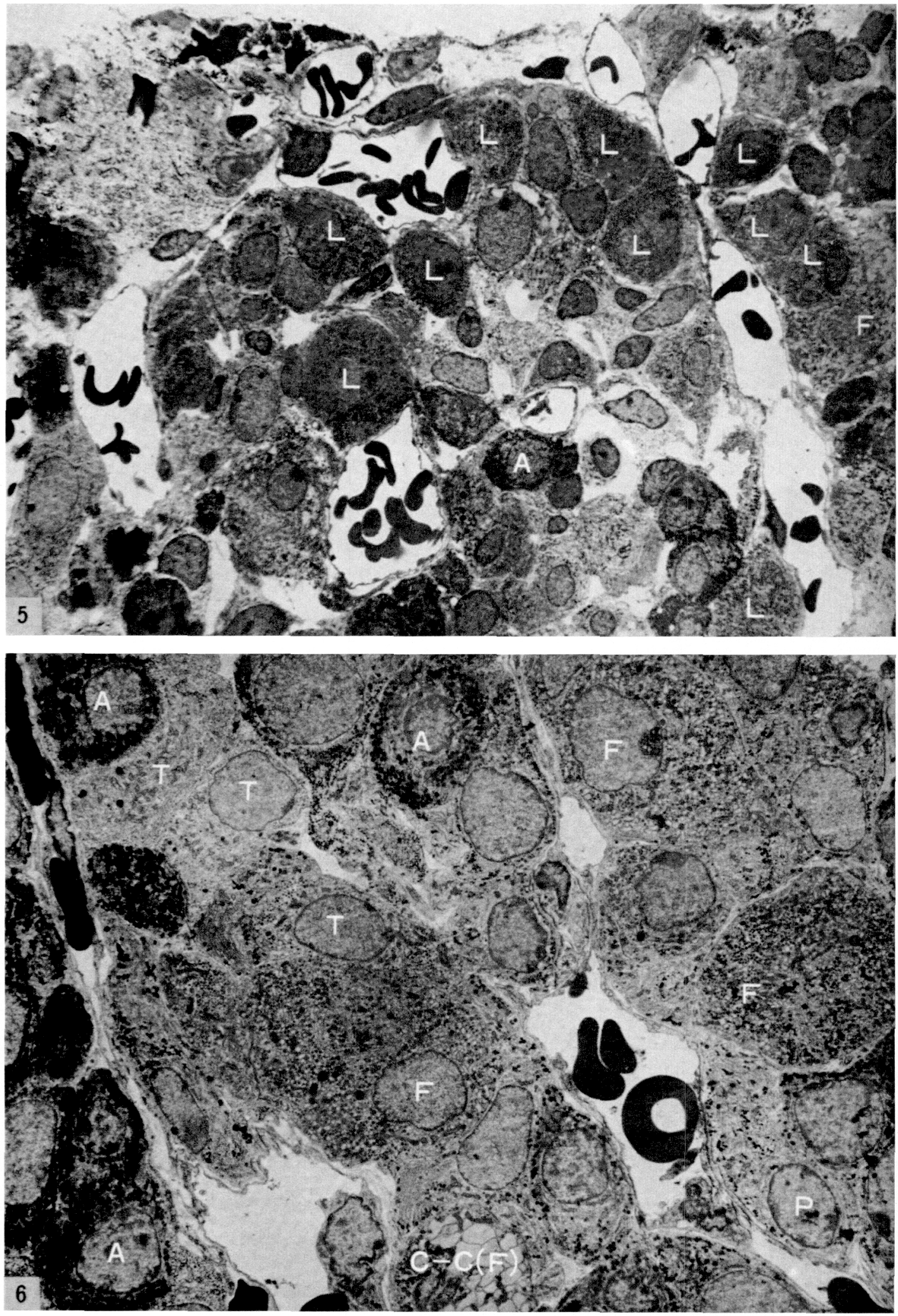
13). Comparison of Figure 13 with Figure 6 would clearly indicate the outstanding granular discharge and excessive dimensional reduction of ER in the central FSH-castration cells. These changes naturally vary in degree from cell to cell. Evident loss of secretory granules from an intermediary cell between the FSHand LH-castration cell was demonstrated in Figure 15. Granule discharging activity of LH$\mathrm{RH}$ is therefore strongly directed to the FSHcastration cells within $10 \mathrm{~min}$. When reduction in size of ER reached the maximum, those cells might assume an appearance of LH-cells devoid of round cisternae (Fig. 14). There was no evidence to show the frequent extrusion of secretory granules from LH- or FSH-cells, and rapid discharge of granules might be due to the other mechanism of granular dissociation. In fact, secretory granules of low electron density with indistinct limiting memberane were often observed (Fig. 14). Cytological difference among the responding gonadotrophs may, therefore, correspond to the different phases of secretory cycle of the same basophil. Reduction in size of ER at this interval was found to be more pronounced than in the controls.

\section{Changes on LH-and FSH-cells, $30 \mathrm{~min}$ after $\mathrm{LH}$-RH injection}

Release of granules from peripheral LHcells was completed within $5 \mathrm{~min}$, spontaneously followed by new granulation. After $30 \mathrm{~min}$, progressive accumulation of secretory granules was seen not only in the peripheral LH-cells but also in some FSH-cells with closed cisternae (Fig. 16). The interval between 10 and 30 min may therefore be regarded as the "synthesizing phase", during which various types of basophils, i.e., polygonal large thy- rotrophs, ovoid small LH-cells and hypertrophied round FSH-cells containing numerous granules, arise in the central area of the gland (Figs. 17, 18, 19). A series of basophils vary from cell to cell with the number, size and shape of ER. Even in a polygonal thyrotrophlike cell, formation of round vesicles took place in their peripheral portion (arrow in Fig. 18), but Golgi-ring was not yet enough developed. It seems of great importance that central LH-cells and thyrotroph-like cells have abundantly reappeared after the discharging phase. In our observation, in this period some FSH-cells had scanty secretory granules (Fig. 19) with a tendency of dilation of cisternae, but some others stored enough of them. Granular accumulation and size are subject to wide variation among the FSH-cells.

\section{Acute and subacute changes of LH-RH on LH-and FSH cells, 60 and $180 \mathrm{~min}$ after injection}

Acute granule discharging activity of LHRH from FSH-castration cells terminated after $30 \mathrm{~min}$. Most of FSH-castration cells showed comprehensive recovery from the primary loss of secretory granules within $60 \mathrm{~min}$, based on the findings under low magnification of the central area of the gland (Fig. 20). Some of these cells are filled with the secretory granules despite the shrunk ER (Fig. 22), but some others contain numerous expanded cisternae, taking the form of fully developed castration cells (Fig. 21). Peripheral ovoid LH-gonadotrophs were generally packed with the secretory granules, as seen in the controls. Since both kinds of gonadotrophs thus accumulated the secretory granules at this interval, they probably belong together to the "storage phase".

$\leftarrow$ Fig. 5. Superficial region of the gland, after a short-term estrogen-progesterone treatment on the 30 th postoperative day, 3 days later, $\times 1,700$. Peripheral LH-gonadotrophs (L) are packed with the secretory granules: A, acidophil.

Fig. 6. Central area of the gland, after a short-term estrogen-progesterone treatment on the same condition, $\times 3,000$. A, acidophil; T, thyrotroph; F, FSH-gonadotroph; P, prolactin cell; C-C(F), castration cell (FSH-gonadotroph). 

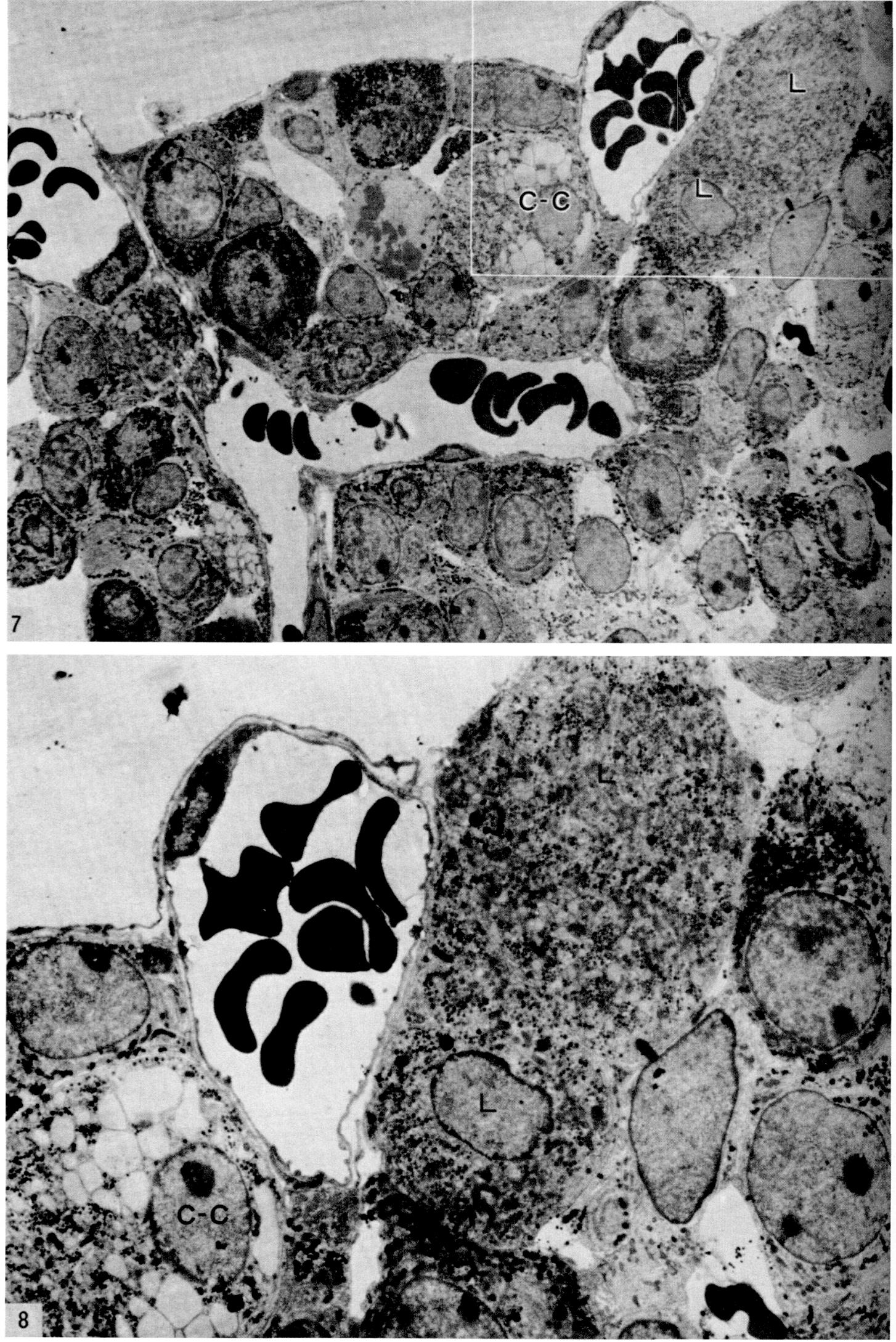


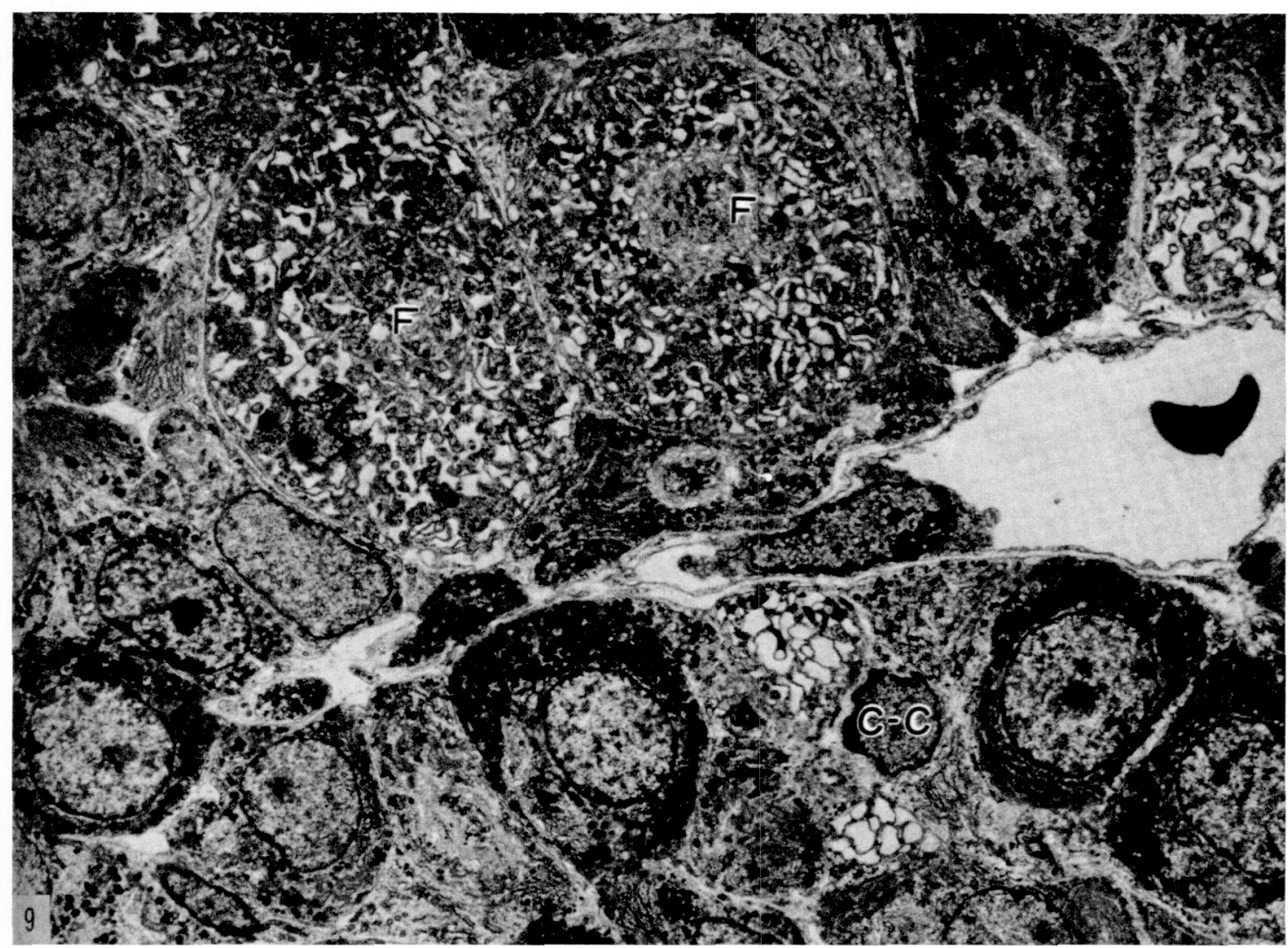

Fig. 9. Central area of the gland, $5 \mathrm{~min} \times 3,000$. This area is interspersed with numerous FSH-castration cells (F) with closed cisternae and promient Golgi-ring, among which fully developed castration cells with open cisternae are interspersed. F, FSH-castration cell.

$\leftarrow$ Fig. 7. An overlook on the peripheral area of the gland, 5 min after LH-RH injection, from a castrated and steroids treated female rat, $\times 2,000$. L, LH-gonadotroph; C-C, castration cell which may originate from $\mathrm{LH}$-gonadotroph.

Fig. 8. Two LH-gonadotrophs, $5 \mathrm{~min} \times 4,000$. The demarcated area seen in Fig. 3 is highly magnified in this Figure. Secretory granules tend to be slightly driven out of these LH-gonadotrophs (L), but still remain numerously. Activity of LH-RH to discharge the secretory granules is mild and temporary by the single injection (100ng/ml/rat). C-C, castration cells filled with the large round vacuoles. 


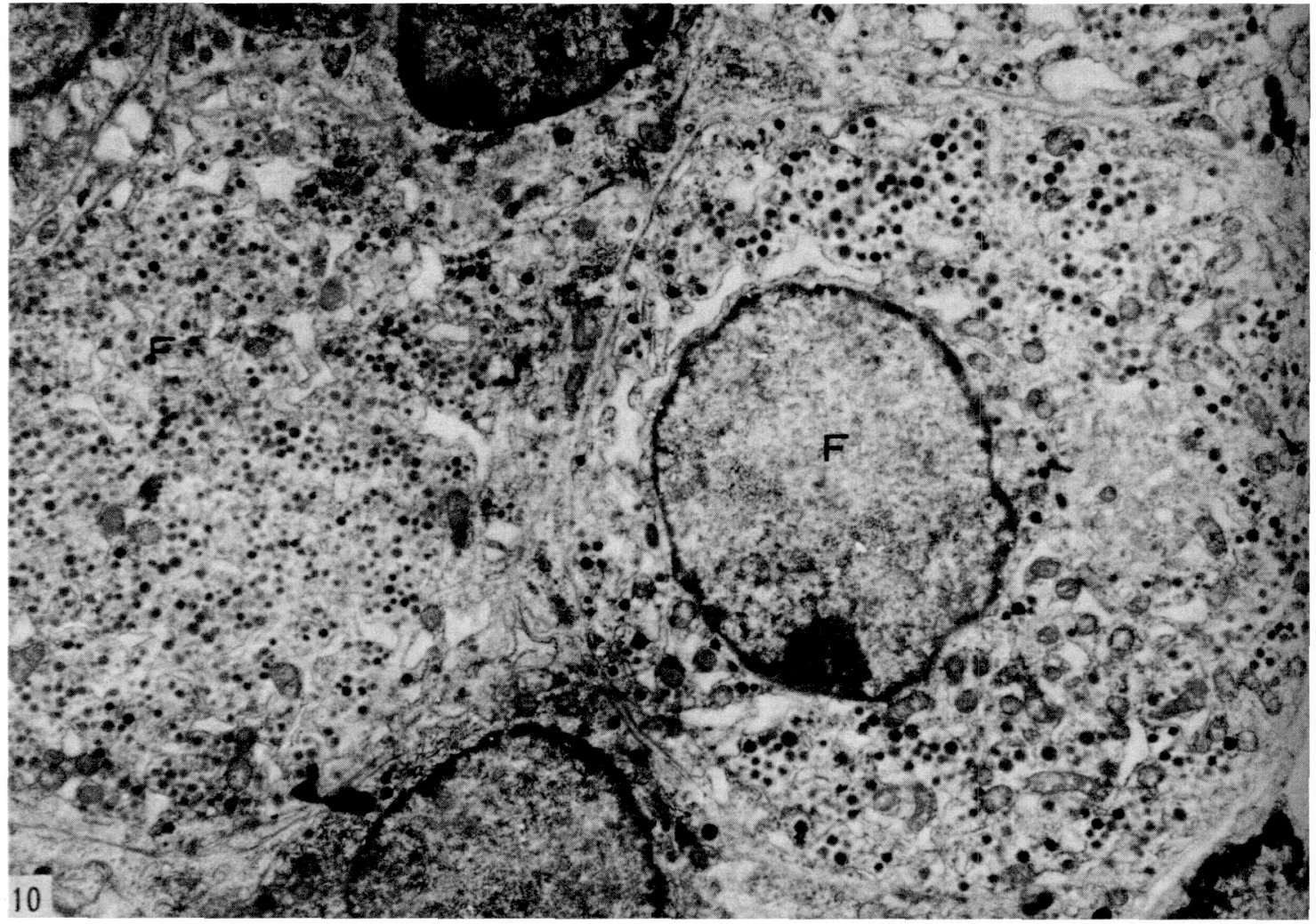

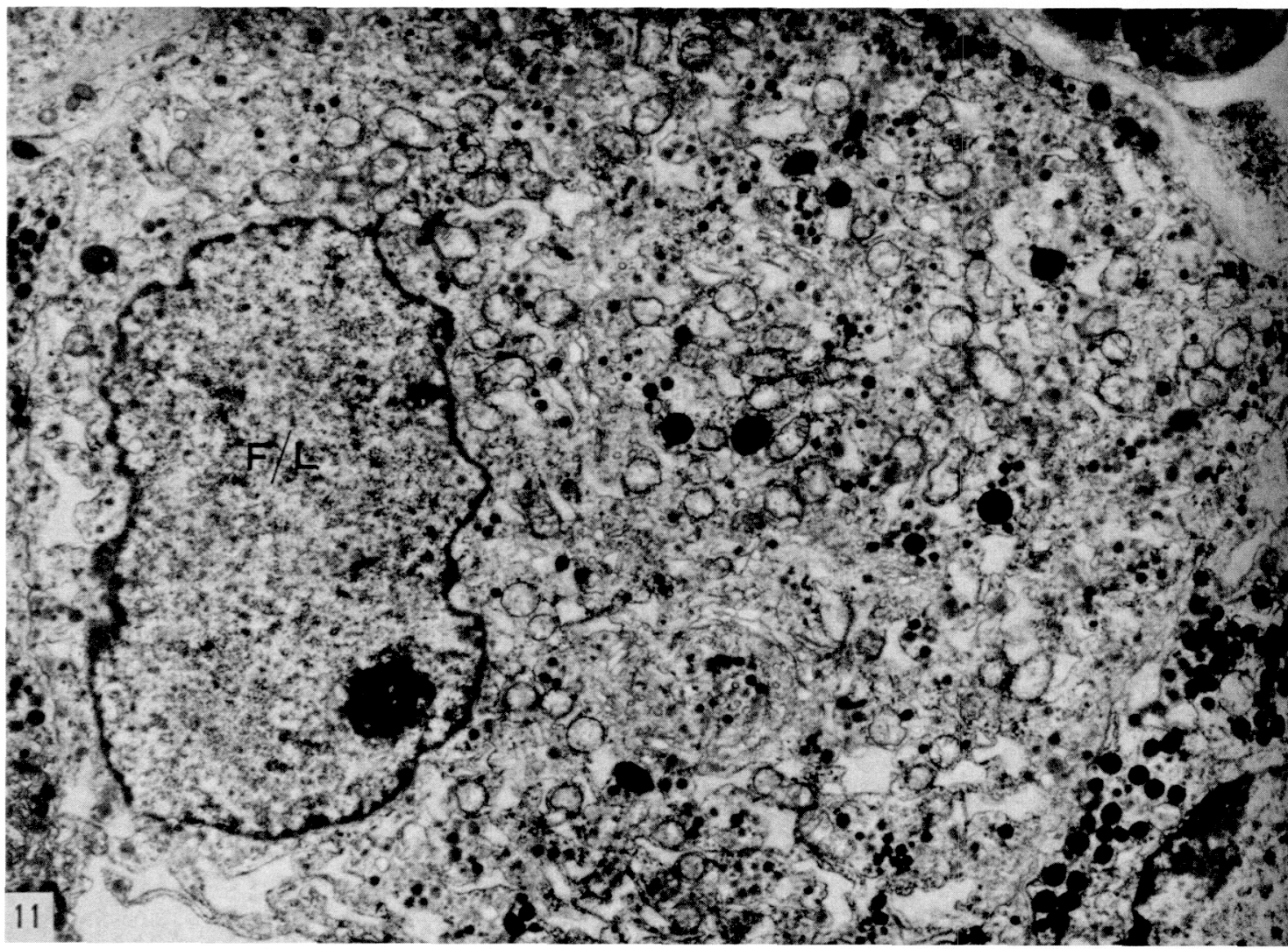


Within $180 \mathrm{~min}$, however, FSH-castration cells showed serious but qualitatively different changes. Cisternae in them recovered from their foregoing shrinkage to dilate and finally fill the cell-bodies, taking an appearance of typical castration cells. Comparisons of Figures 23 and 24 with Figure 20 clearly show the conspicuous dilation of cisternae, sometimes forming lace mosaic picture, with the lapse of time. The size, shape and number of cisternae corresponded with those in the castrates without steroids treatment (Fig. 4). Thus, the central area of the gland was filled with the FSH-castration cells characterized by numerous open cisternae and prominent Golgi-ring (Figs. 24) in the subacute phase of LH-RH injection. Intraplasmic secretory granules varied considerably in number from cell to cell. In this interval, agranular castration cells were frequently detected (Fig. 25). Reduction in number of secretory granules may account for the mild but prolonged secretion from FSH-gonadotrophs in the subacute phase. The secretory granules accumulated in the peripheral LH-gonadotrophs, on the contrary, failed to be released in this time interval.

\section{Discussion}

Following our foregoing paper on the cytokinetic action of synthetic LH-RH upon a series of pituitary basophils in immature male rats (Yoshimura et al. 1973), the present investigation was made with the materials of castrated female rats with steroids pretreatment. Present radioimmunoassay data informed us the high serum $\mathrm{LH}$ content at 5 and
10 min after $\mathrm{LH}-\mathrm{RH}$ injection, but the mean pituitary LH content showed little change except for diminution after 5 and $180 \mathrm{~min}$. According to the present electron microscopic examination, secretory granules were transiently and slightly discharged from peripheral LH-gonadotrophs only after $5 \mathrm{~min}$, but remarkably from FSH-gonadotrophs after $10 \mathrm{~min}$. The assay data and electron microscopic findings especially as to the quantitative change of secretory granules were compatible with each other. The lowest value of pituitary LH content after 180 min coincides with the mild but prolonged secondary discharge of secretory granules from FSH-castration cells despite a small rise in serum LH content. Present values of the pituitary FSH content (Fig. 2) in ovariectomized rats with estrogen and progesterone pretreatment were near to $363.5 \mu \mathrm{g} /$ pit. expressed in term of NIAMD rat FSH-RP-1 by Libertun et al., (1974) in rats under the same condition. Present values of the pituitary LH content (Fig. 2) look too high, but they may be justifiably evaluated, because the value of $11.5 \mu \mathrm{g}$ NIH LH-S14/mg represented by Rennels et al. (1971) is equivalent through conversion to $379.5 \mu \mathrm{g}$ NIAMD rat LH RP-1/mg and consequently to 3036.0 $\mu \mathrm{g} /$ pit. if pituitary wet weight is tentatively $8 \mathrm{mg}$, and further because the value of $85.0 \mu \mathrm{g}$ NIH LH-S1/pit. represented by Libertun et al. (1974) corresponds through conversion to $2805.0 \mu \mathrm{g}$ NIAMD rat LH-RP-1/pit. Synthetic LH-RH thus exerted a strong effect upon LH release into blood, but only a slight effect upon FSH release. It has been recently postulated by Schally et al. (1972) and Ridding et al. (1972) that synthetic LH-RH/FSH-RH has an activity

$\leftarrow$ Fig. 10. FSH-gonadotrophs in the central area, $5 \mathrm{~min}, \times 6,000$. Since activity of LH-RH to release the secretory granules from FSH-castration cells is not yet complete, numerous secretory granules still remain, cisternae are shrunken.

Fig. 11. Possible transitional form between the FSH- and LH-gonadotrophs, 5 min $\times 7,000$. Despite infrequent occurrence of small granules of $150 \mathrm{~m} \mu \sim 200 \mathrm{~m} \mu$ in diameter, this ovoid cell resembling the LH-gonadotroph in structure may belong to a transitional form. F/L, intermediary form between FSH- and LH-castration cell. The similarity of its fine structure to the above FSH-cells and to the LH-cells shown in Figure 8 is noted. 

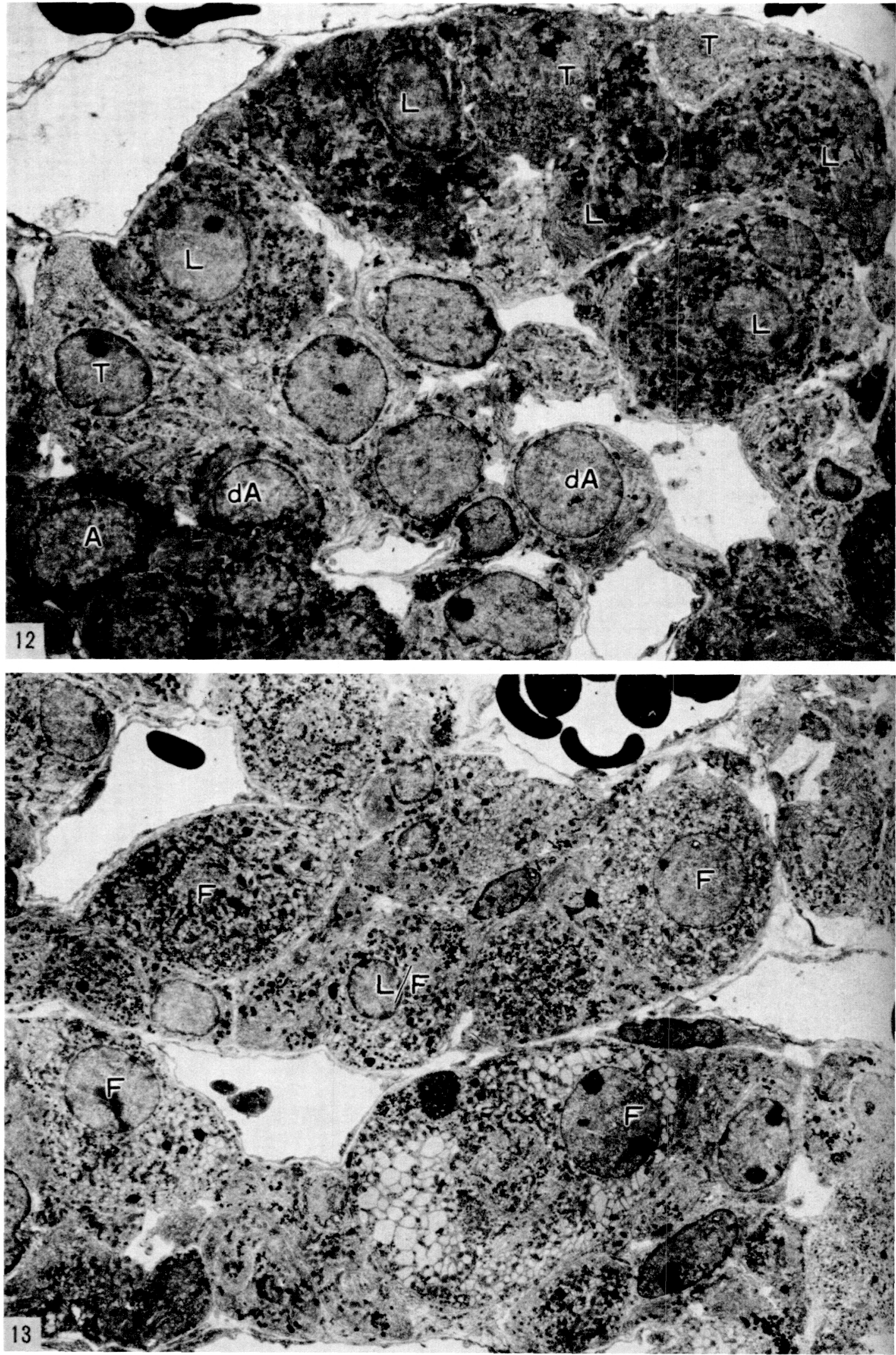
to release both the LH and FSH under in rivo and in vitro condition. To date, it has not been possible to separate LH releasing activity from FSH releasing activity and both properties appear to be intrinsic to the same molecule of LH-RH/FSH-RH (Arimura et al., 1972). This problem was, however, not decided certainly in this study.

Morphological evidences were presented that predominant castration cells found in the controls probably originated from FSHgonadotrophs despite the infrequent detection of castration cells of peripheral LH-gonadotroph origin, and that the central area of the gland, on the other hand, was particularly devoid of LH-cells. In our opinion, central LH-gonadotrophs may transform into FSHgonadotrophs, followed by conversion into castration cells after gonadectomy (Yoshimura et al. 1973). The close relationship between the high pituitary LH content and the high population of FSH-castration cells may cast a question to the current view of ascribing the role of LH secretion only to so-called LH gonadotrophs. Rennels et al. (1971) examined the acute fine structural changes of the castration cells in the ovariectomized and estrogenprogesterone treated rats after the injection of $100 \mathrm{ng}$ LH-RH. They found no morphological signs of accelerated LH release in castration cells in spite of evidence of intensive release of LH from the pituitary. Mendoza et al. (1973) pointed out, in their acute experiment on LH$\mathrm{RH}$, that LH-gonadotrophs were the only cells responsible for $\mathrm{LH}$ secretion. They stressed the exaggerated extrusion of granules through the cytomembrance as the main response of LH-cells to $\mathrm{LH}-\mathrm{RH}$, and pointed out the peroxidase labeled antibody reactivity of the signet-ring cells and marked increase in number of these cells with positive peroxidase reaction $3 \mathrm{~min}$ after $\mathrm{LH}-\mathrm{RH}$ injection. The present electron microscopic findings, contray to the view of Mendoza et al., showed the simultaneous action of LH-RH upon both kinds of gonadotrophs. According to our present findings LH-RH exerts a transient and mild action upon peripheral LH-cells to release their secretory granules only $5 \mathrm{~min}$ after administration, followed by an intense action upon FSH-cells to drive out their secretory granules 5 to $30 \mathrm{~min}$ after injection. According to our morphological and assay data, LH-RH exerted the intense and transient primary effect on discharge of $\mathrm{LH}$ and secretory granules from the FSH-castration cells in the early phase ( 5 and $10 \mathrm{~min}$ ) followed by the mild and prolonged effect on concomitant discharge of LH and secretory granules from the FSH-castration cells, but not from LHgonadotrophs, in the subacute period (180 min) through the storage phase. This noteworthy biphasic response of FSH-castration cells to LH-RH might indicate that the LHcells are not always the genuine target cells of LH-RH, but both the LH- and FSH-gonadotrophs deserve the secretory source of LH.

LH-cells might possibly represent the prestage of FSH-gonadotrophs, and LH- and FSHgonadotrophs are not independent cell types, but merely represent different phases of the secretory cycle of the same basophil according to Yoshimura et al. (1974). Debeljuk et al. (1973) confirmed the chronic effect of LH-RH upon FSH-gonadotrophs in the pituitary grafts under the renal capsule to release the secretory granules. LH-gonadotrophs identified by Kurosumi (1968) and Rennels and his associates (Shiino et al., 1972) may be quite different in their fine structure from the

$\leftarrow$ Figs. 12 and 13. Overlooks on the peripheral and central area of the gland $\times 3,000$, $\times 3,000,10 \mathrm{~min}$ after LH-RH injection, from a castrated and steroid-treated female rat. Peripheral LH-gonadotrophs (L) store enough secretory granules in this interval, while many central FSH-castration cells (F) contain the diminished number of secretory granules. T, thyrotroph; A, acidophil; dA, degranulated acidophil; L/F, intermediary form between LH- and FSH-gonadotroph. 


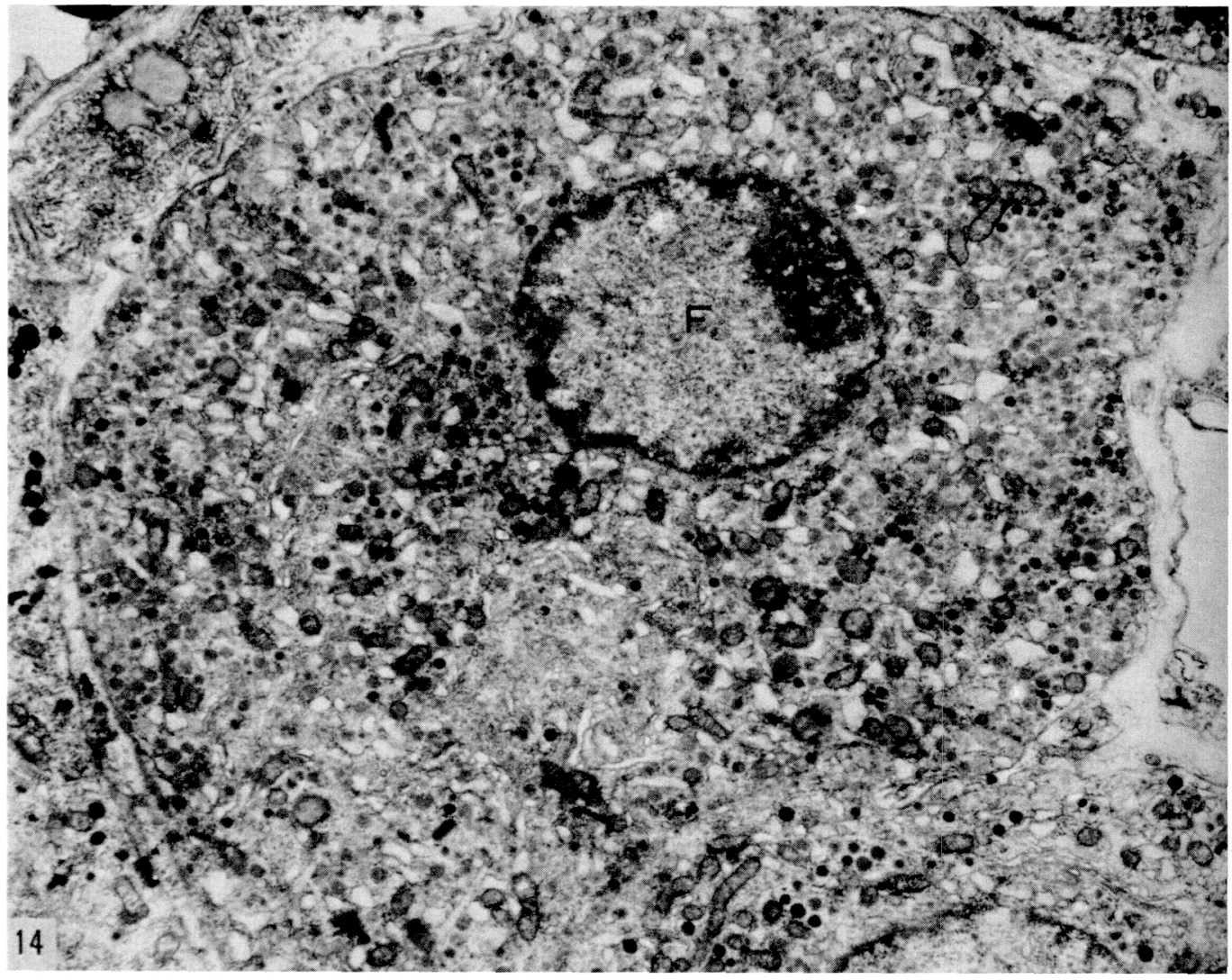

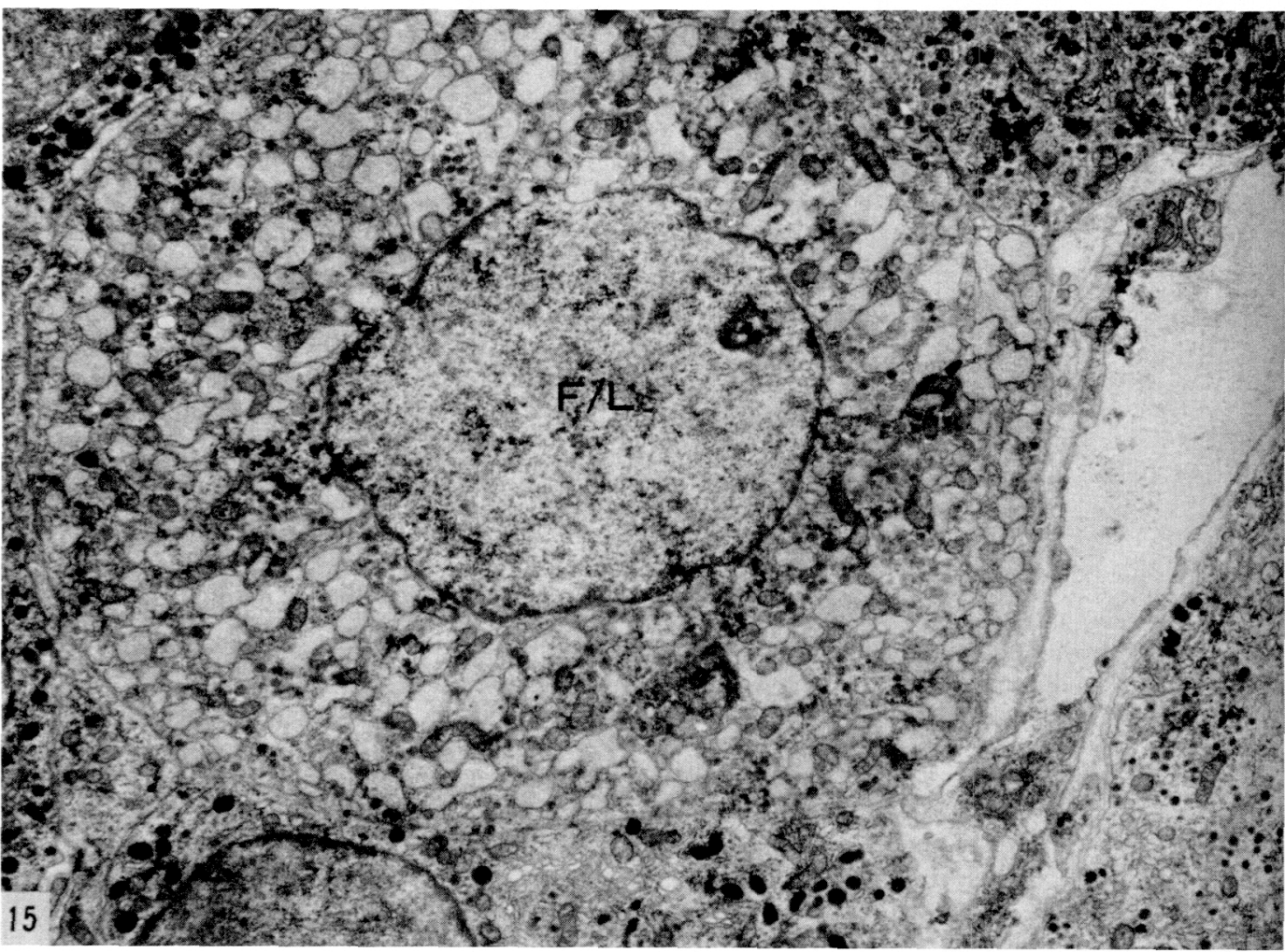




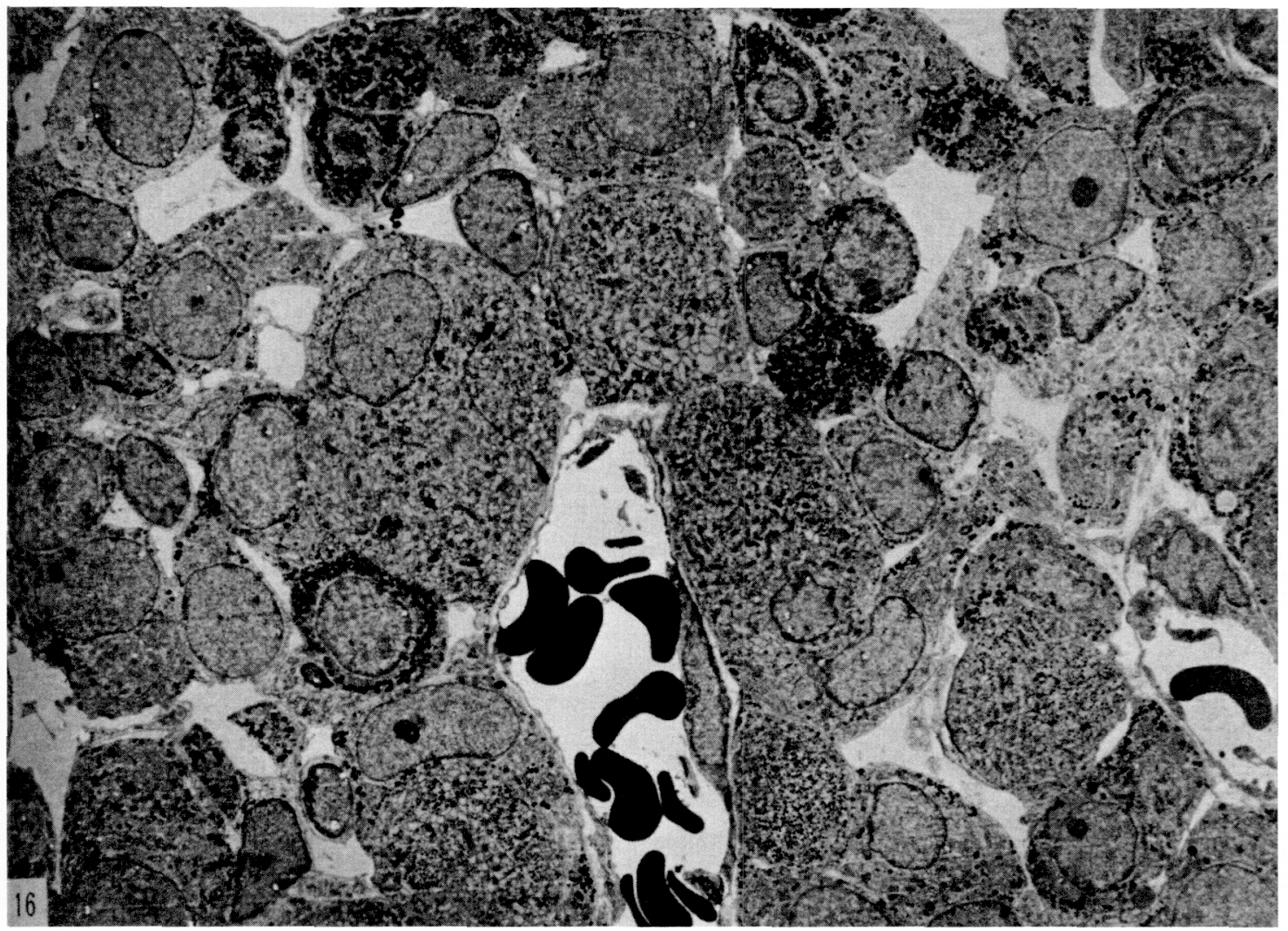

Fig. 16. A general view of accumulated FSH-castration cells in the central area, 30 min after LH-RH injection in a castrated and steroids treated female rat. $\times 2,000$. These cells produce their secretory granules in this interval and store again in their cell-bodies in which all the cisternae are enough closed.

$\leftarrow$ Figs. 14 and 15. A FSH-castration cell and an intermediary form $(\mathrm{F} / \mathrm{L})$ between FSHand $\mathrm{LH}$-castration cell, $10 \mathrm{~min} \times 6,000, \times 6,000$. Acute effect of $\mathrm{LH}-\mathrm{RH}$ to release the secretory granules is conspicuous especially in the latter as seen in Figure 11. Co-existence of secretory granules of low density within the cells is shown in Figure 14. $\mathrm{F} / \mathrm{L}$ becomes scanty of granules in parallel to the advancement in dilation of cisternae. The structure of this kind of cell may mean the intermediary step from LH- to FSHgonadotrophs. 

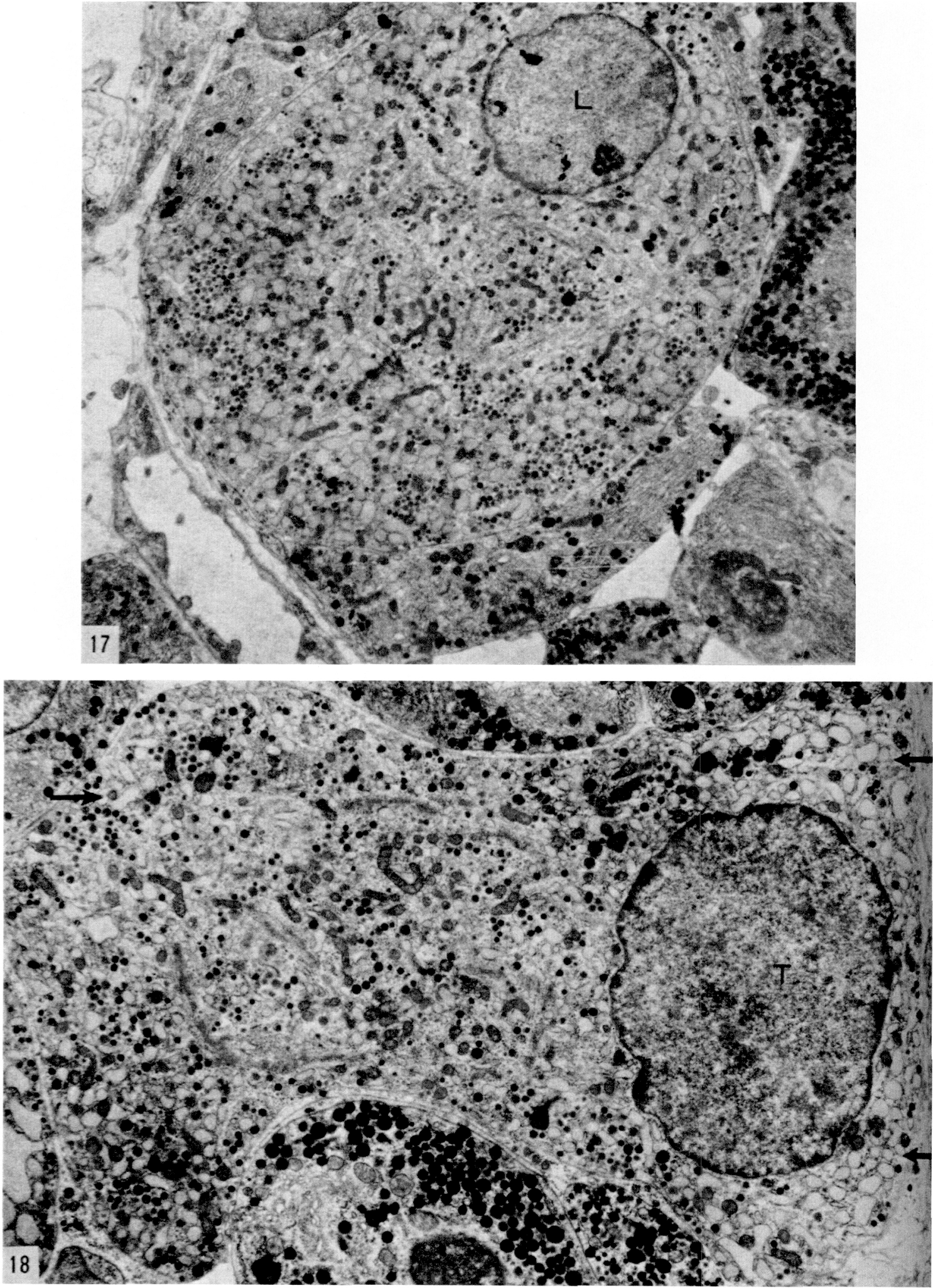
peripheral LH-gonadotrophs identified by us. Yoshimura et al. (1974) doubted the reality of Kurosumi's LH-gonadotrophs and tentatively regarded them as "acidophils of the small granule type". The phenomenon of discharge of granules by extrusion system, found in acidophils but not in basophils, should be regarded as the abnormal or unusual mode of secretion. The present results thus tend to sup- port the concept of the cycle of the basophil proposed by Yoshimura et al. Our consideration is given concerning the functional significance of so-called peripheral LH-gonadotrophs: They did not make easily affection after castration and steroid pretreatment, and further gave rise to less response to $\mathrm{LH}$ $\mathrm{RH}$ than the FSH-castration cells. Central LHgonadotrophs were, on the other hand, sus-

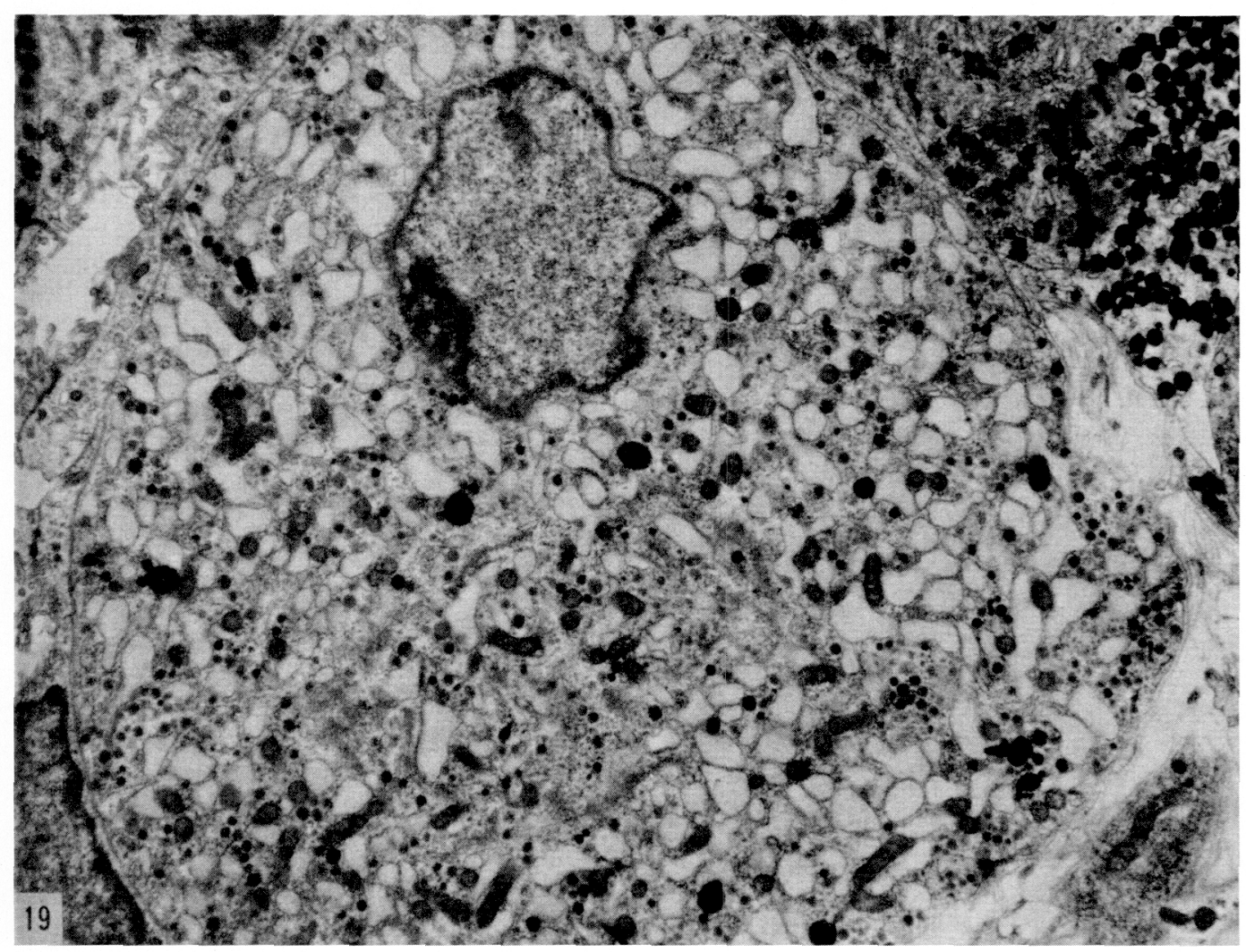

Fig. 19. A FSH-castration cell containing a small number of secretory granules, $30 \mathrm{~min}$, $\times 6,000$. Granularity varies from cell to cell, but this cell may be in the end of the primary discharging phase. Dilation of cisternae and reduction in size of scanty granules measuring about $150 \mathrm{~m} \mu$ are the two main events in this cell. Thus the size of the granules is possibly changeable.

$\leftarrow$ Figs. 17 and 18. A LH-gonadotroph and a thyrotroph in the central area of the gland, $30 \mathrm{~min}, \times 5,000, \times 7,000$. Various types of basophils are found in the central area, where a LH-gonadotroph containing numerous secretory granules and round vesicles reappears concurrently. A polygonal thyrotroph containing numerous small granules $130 \sim 180 \mathrm{~m} \mu$ in diameter produces the vesicles at the periphery of the cell-body (arrow). From these cytological characteristics, the onset of possible transition may be suggested between thyrotroph and LH-gonadotroph. In the next stage, growing size of granules and marked vesiculation in the LH-cells may result in the gradual transformation into the FSH-cells. 

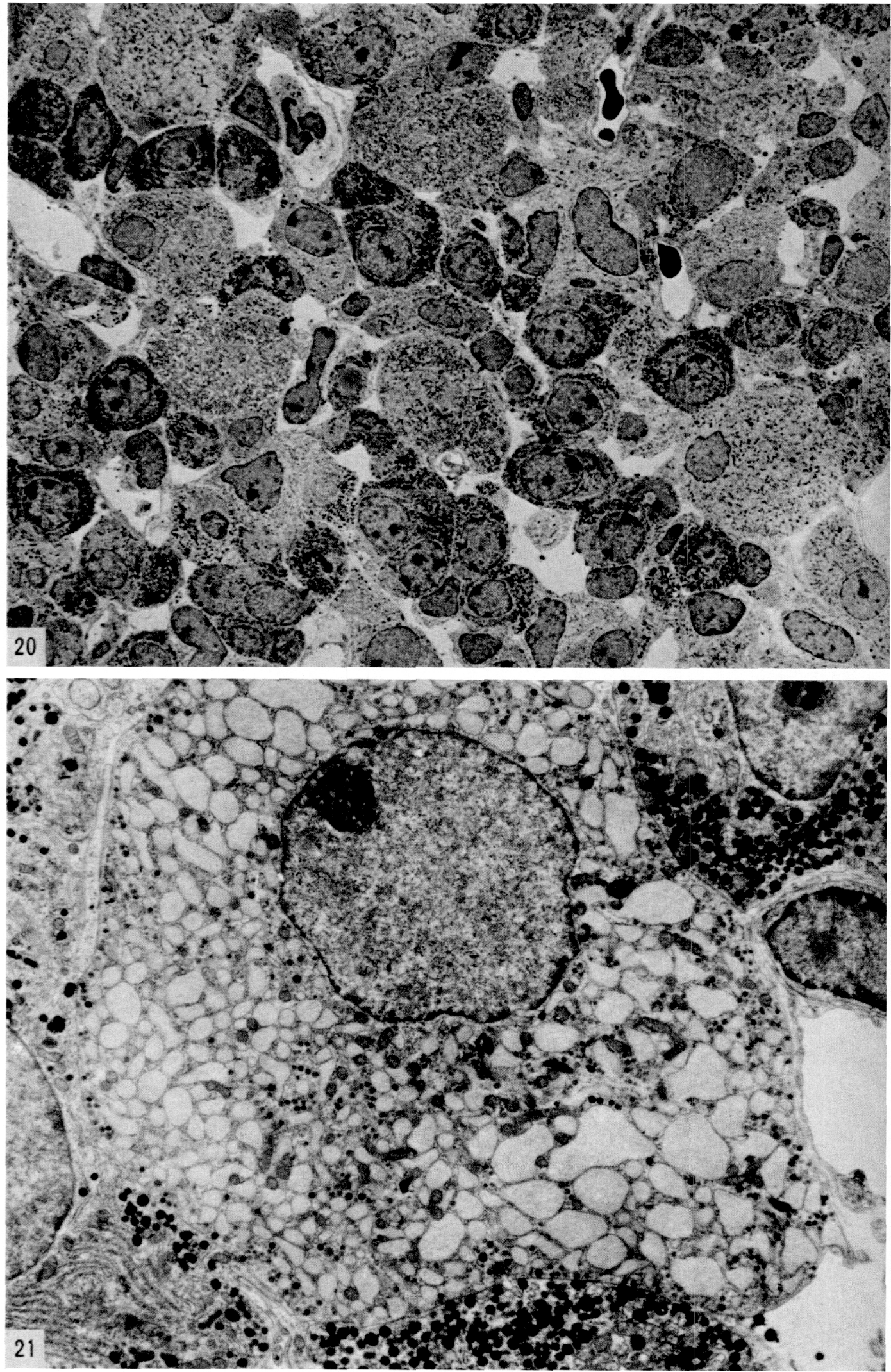
ceptible of being affected with the consequent transformation into FSH-gonadotrophs. It may be speculated from these findings that peripheral LH-gonadotrophs are fixed cells in performance of secretory cycle, while central LH-gonadotrophs carry out the active secretory cycle taking a fashion of transformation into FSH-goandotrophs and/or castration cells. The real significance of peripheral LHgonadotrophs has not been determined, so that further studies are now undertaken from the view-point of long-term stimulation by the releasing hormone.

In conclusion, the results of present study do not support the independent presence of $\mathrm{LH}$ gonadotrophs with selective response to $\mathrm{LH}$ -

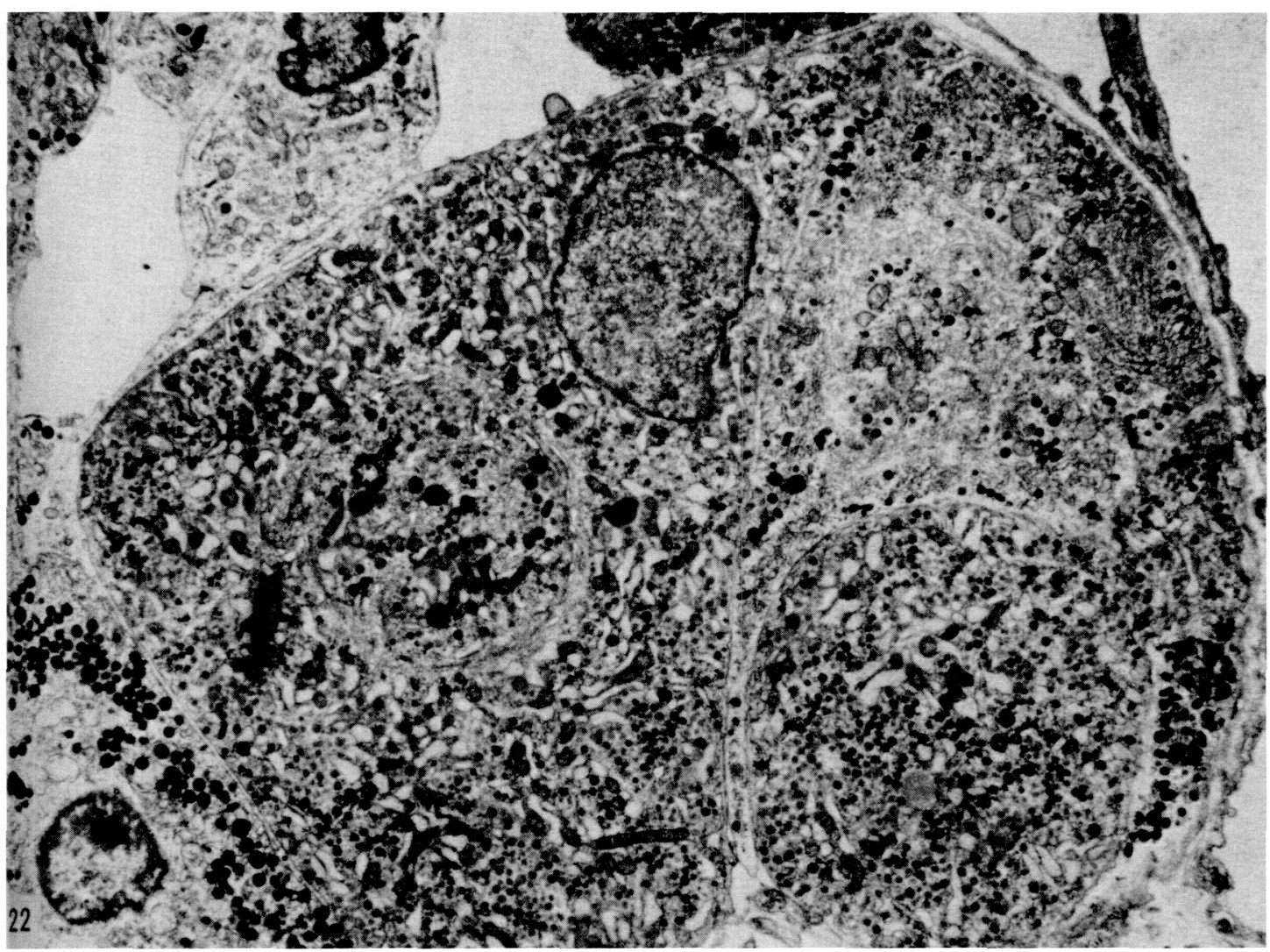

Fig. 22. Storage type of FSH-castration cells commonly detectable in the central area, 60 min after injection, $\times 5,000$. Together with the extremely closed cisternae, a great number of secretory granules are stored in these FSH-castration cells, which were already shown in Figure 20 in low magnification.

$\leftarrow$ Fig. 20. A general view of the central area in the gland, $60 \mathrm{~min}$ after injection from a castrated and steroids treated female rats. $\times 1,300$. In most FSH-castration cells, the closure of cisternae is maximal in degree and their storage granules are quite numerous in this interval.

Fig. 21. Occurrence of a small number of fully developed FSH-castration cells, 60 min after injection, $\times 7,000$ Among common FSH-castration cells, the profoundly affected castration cells appear infrequently. With the advancement in dilation of cisternae, however, secretory granules are exceedingly reduced in size and diameter in these cells. 

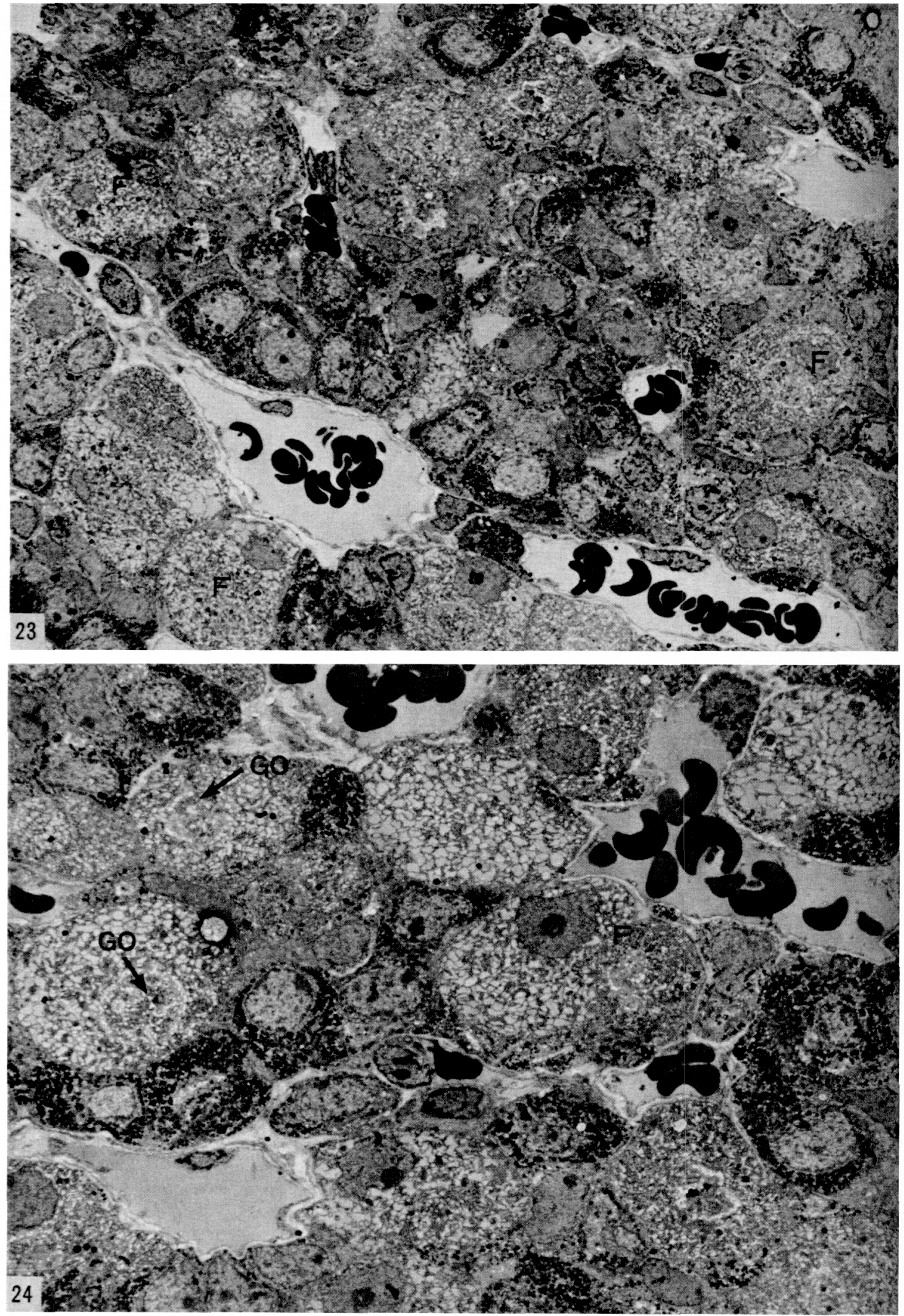
RH. Recently, Phifer et al. (1973) showed the immunohistologic and histologic evidence that FSH and LH were present in the same cell type in human pars distalis by an immunoglobulin peroxidase bridge procedure, and further revealed that the gonadotrophic cells selectively stained with alcian blue periodic acid silver orange $G$ contained two apparently different granule types. Our present results were compatible with the im- munohistologic evidences by Phifer et al.

\section{References}

Arimura A., L. Debeljuk and A. V. Schally

(1972). Endocrinology 91, 529.

Arimura A., L. Debeljuk, M. Shiino, E. G.

Rennels and A. V. Schally (1973). Ibid. 92, 1507.

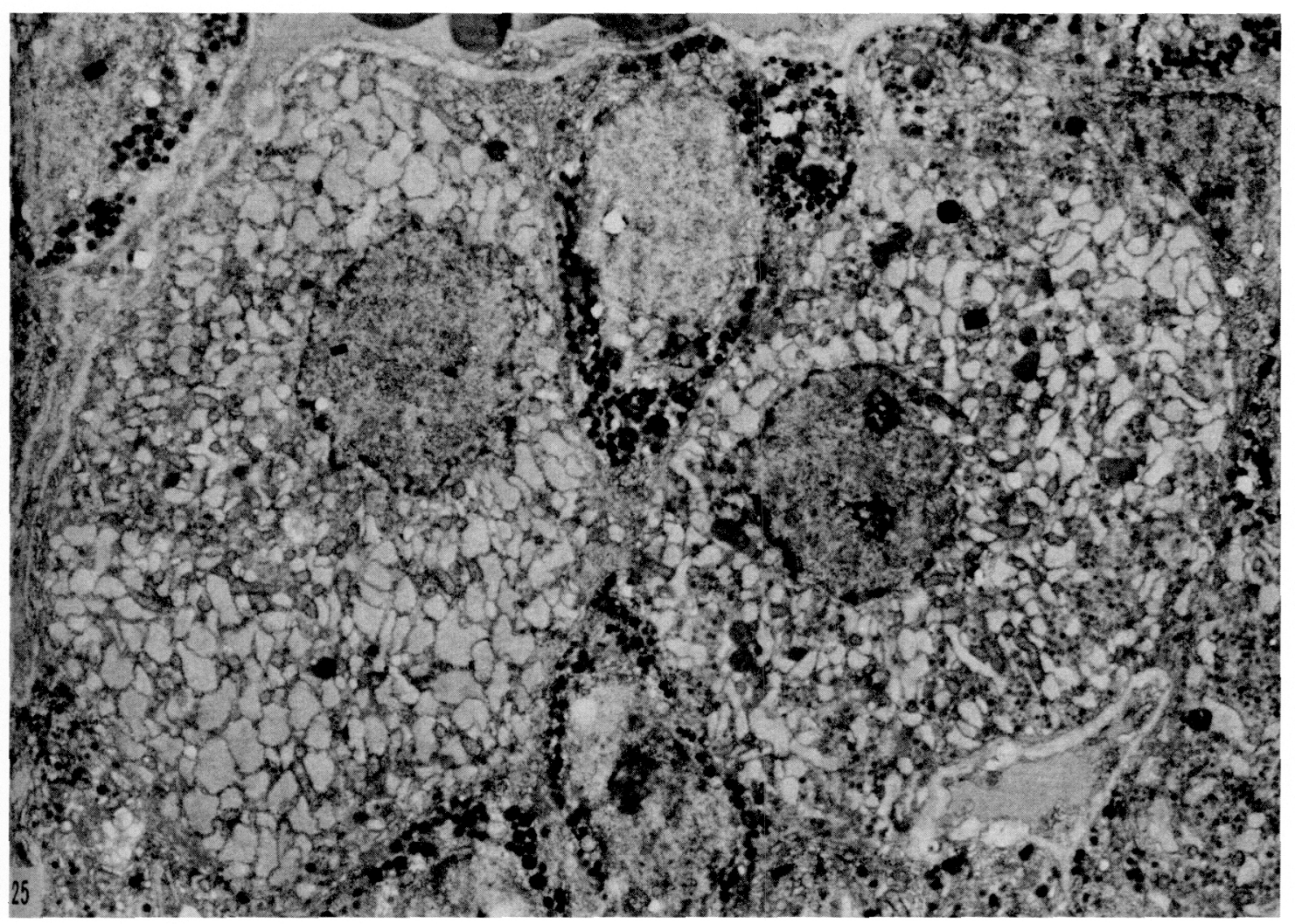

Fig. 25. Two FSH-castration cells during the secondarily prolonged discharging phase, 180 min. $\times 5,000$. During this subacute phase, most of castration cells storing the secretory granules have changed to lose the granules. These two cells belong to "agranular castration cells" with open cisternae probably due to the elaborated secretion.

- Figs. 23 and 24. Overlooks on accumulated FSH-castration cells with open cisternae in the central area, 180 min after injection, from a castrated and steroids treated female rat. $\times 1,300, \times 2,500$. The central area is scattered by this kind of cells $(F)$ which are characterized by the huged, irregularly shaped cisternae, sometimes representing the lace mosaic pattern. Golgi-ring (Go) is obviously enlarged. 
Brain J. and C. Ezrin (1970). J. Clin. Endocrinol. 30, 181.

Baker B. L., J. G. Pierce and J. S. Cornell (1972). Am. J. Anat. 135, 251.

Barnett R. J., E. J. Ladman, N. J. McAllaster and E. R. Siperstein (1956). Endocrinology 59, 398.

Daane T. and A. F. Parlow (1971). Ibid. 88, 1261.

Debeljuk L., A. Arimura, M. Shiino and E. G. Rennels (1973). Ibid. 92, 921.

Dubois M. P. (1971). Ann. Peck. Vet. 2, 197.

Herlant M. and F. Ectors (1969). C. R. Acad. Sci. (Paris) 269, 368.

Kurosumi K. (1968). Arch. Histol. Jap. 29, 329.

Libertun C., K. J. Cooper, C. P. Fawcett and S. M. McCann (1974). Endocrinology 94, 518.

Mendoza D., A. Arimura and A. V. Schally (1973). Ibid. 92, 1153.

Mirecka J. and A. G. E. Pearse (1971). Folia Histochem. Cytochem. (Krakow) 9, 365.
Nakane P. K. (1970). J. Histochem. and Cytochem. 18, 9.

Phifer R. F., A. R. Midgley and S. S. Spicer (1973). J. Clin. Endocrin. 36, 125.

Redding T. W., A. V. Schally, A. Arimura and H. Matsuo (1972). Endocrinology 90, 764.

Rennels E. G., E. M. Bogdanove, A. Arimura, M. Saito and A. V. Schally (1971). Ibid. 88, 1318.

Reynalds E. S. (1963). J. Cell Biol. 17, 208.

Schally A. V., T. W. Redding, H. Matsuo and A. Arimura (1972). Endocrinology 90, 1561. Shiino M., A. Arimura, A. V. Schally and E. G. Rennels (1972). Z. Zellforsch. 128, 152.

Wakabayashi K., Antunes-Rodrigues, B. Tamaoki and S. M. McCann (1972). Endocrin$\operatorname{ology}$ 90, 690.

Yoshimura F., T. Soji, M. Igarasli and K. Taya (1973). LH/FSH Releasing Hormone, Tokyo. p. 196.

Yoshimura F., T. Soji, H. Yachi and H. Ishikawa (1974). Endocrinol. Japon. 21, 217. 